\title{
PEMAAFAN PADA KELUARGA KORBAN LEDAKAN BOM DI SURABAYA
}

\section{Charis Pratama \& Wahyuni Kristinawati}

Universitas Kristen Satya Wacana, Jl. Diponegoro 52-60, Salatiga, Indonesia

Korespondensi: charispratama97@gmail.com

\section{FORGIVENESS OF FAMILY VICTIMS OF BOMB EXPLOSION IN SURABAYA}

\begin{abstract}
Technological disasters resulting in the death of family members can cause deep sadness and anger to individuals. Despite causing deep psychological trauma, individuals perceive and react differently towards the incidents. The purpose of this study is to describe forgiveness process of individuals who lost family members (children and spouses) in the bomb terror incident in Surabaya. This study used a deductive qualitative method to two participants, with interpersonal process of forgiveness and unforgiveness theory as framework. Data was analyzed using thematic analysis strategy. Four main themes emerged from the study related to the forgiveness fo the victims: personal context (personality trait and religious commitment), post-event perception, emotional responses, and behavioral responses. The study demonstrated that forgiveness is a unique process, which is experienced differently among individuals, depending on their personality traits, religious commitments, and perception of events which then affect the emotional response and behavior of individuals towards the transgressors.
\end{abstract}

Manuscript type: Original Research

\section{Article history:}

Received 8 December 2019

Received in revised form 19 March 2020

Accepted 28 May 2020

Available online 3 August 2020

\section{Keywords:}

anger

forgiveness

post-traumatic

sadness

technological disaster

\begin{abstract}
Abstrak
Bencana teknologi yang menyebabkan meninggalnya anggota keluarga dapat menimbulkan kesedihan dan kemarahan pada individu. Meski mengalami trauma yang serius, persepsi serta reaksi individu atas bencana tersebut beragam. Tujuan penelitian ini adalah untuk mengetahui gambaran proses pemaafan pada individu yang kehilangan anggota keluarga (anak dan pasangan) dalam peristiwa bom di Surabaya. Penelitian ini menggunakan pendekatan kualitatif deduktif terhadap dua partisipan, dengan teori interpersonal process of forgiveness and unforgiveness sebagai kerangka berpikir. Analisis tematik digunakan sebagai metode analisis data. Hasil penelitian menunjukan terdapat empat tema utama mengenai pemaafan pada korban: konteks personal (ciri kepribadian dan komitmen agama), persepsi pasca kejadian, respons emosional, dan respons perilaku. Penelitian ini menunjukkan bahwa proses pemaafan dapat berbeda antara satu individu dan individu yang lain, bergantung pada perbedaan ciri kepribadian, komitmen agama, dan persepsi terhadap kejadian yang memengaruhi respons emosional dan perilaku individu terhadap pihak yang dianggap bersalah.
\end{abstract}

Kata Kunci: bencana teknologi, kemarahan, kesedihan, pasca trauma, pemaafan

\section{Dampak dan Implikasi dalam Konteks Ulayat}

Kematian orang terdekat menyisakan kesedihan bagi individu, terlebih kematian karena adanya bencana teknologi (seperti peristiwa bom bunuh diri) dapat menimbulkan kemarahan dan penyangkalan atas peristiwa yang terjadi. Mengenai hal tersebut, konsep kearifan lokal Kawruh Jiwa Ki Ageng Suryomentaram memandang perlu bagi individu untuk berdamai dengan masa lalu dan memfokuskan diri pada keadaan "yang nyata" saat ini dan dapat menerima keadaan dengan sepenuh hati tanpa kuasa untuk memiliki pilihan lain (saiki, kene, ngene yo gelem). Studi ini menunjukkan bahwa konsep Kawruh Jiwa tercermin melalui kebesaran hati keluarga korban ledakan bom di Surabaya untuk berdamai dengan pihak yang dianggap bersalah (transgressor).

Handling Editor: Karel Karsten Himawan, Faculty of Psychology, Universitas Pelita Harapan, Indonesia This open access article is licensed under Creative Commons Attribution License, which permits unrestricted use, distribution, and reproduction, provided the original work is properly cited. 


\section{PENDAHULUAN}

\section{Latar Belakang}

Tanggal 13 Mei 2018 merupakan hari yang tidak dapat dilupakan oleh bangsa Indonesia, khususnya warga Surabaya. Pasalnya di hari tersebut terjadi ledakan bom di beberapa tempat di kota Surabaya. Beberapa tempat yang terkena ledakan bom adalah Gereja Kristen Indonesia (GKI) Diponegoro, Gereja Santa Maria Tak Bercela (SMTB), dan Gereja Pantekosta Pusat Surabaya (GPPS) Jalan Arjuno, dengan jumlah korban tewas sebanyak 11 orang dan 41 orang mengalami luka berat dan ringan (Kami, 2018).

Meski banyak keluarga korban yang merasakan kesedihan mendalam akibat peristiwa tersebut. Terdapat beberapa keluarga korban yang menyatakan telah memaafkan teroris yang menewaskan anggota keluarganya. Seorang keluarga korban mengungkapkan bahwa dirinya ikhlas melepas anaknya ke pangkuan Tuhan dan mengampuni teroris yang menewaskan anaknya ("Kisah haru Wenny, ibunda Evan \& Nathan maafkan pelaku bom bunuh diri”, 2018). Seorang lainnya menyatakan bahwa dari awal dirinya sudah memaafkan pelaku yang menewaskan suaminya dan dapat menerima serta mendoakan para korban dan pelaku agar mendapatkan pengampunan (Abidin, 2018).

Dalam proses pemaafan tentunya terdapat berbagai macam hal yang melatarbelakangi keputusan individu untuk memaafkan transgressor (McCullough, 2000; McCullough, 2001; Worthington Jr. \& Wade, 1999). Di samping itu, berbagai perasaan seperti rasa trauma, ketakutan, kemarahan, dan kesedihan yang mendalam dapat menjadi hal berat untuk korban dapat memaafkan para teroris yang membunuh anggota keluarga mereka. Ini sebabnya kehilangan anggota keluarga akibat bencana teknologi menimbulkan trauma yang lebih besar dibandingkan akibat bencana alam karena adanya kecenderungan individu untuk menyalahkan pihak yang dianggap bersalah atas meninggalnya anggota keluarga mereka (Oliver, 2002). Saka dan Cohen-Louck (2014) menemukan bahwa mayoritas orang tua yang anaknya menjadi korban terorisme mempersepsikan teroris sebagai objek kemarahan, kebencian, balas dendam, dan layak untuk mendapatkan balasan yang setimpal. Hanya beberapa orang tua saja yang berempati terhadap teroris, sedangkan orang tua lainnya mengalami dilema antara berempati dan membenci. 


\section{Pandangan Teoretis tentang Pemaafan}

Secara teoretis, pemaafan merupakan dorongan individu untuk melakukan kebaikan dan menurunkan motivasi untuk menghindari atau membalas dendam terhadap pihak yang menyakitinya, sehingga dapat memulihkan hubungan antara individu dengan pihak yang menyakitinya (McCullough, 2001). Enright (1991) mengemukakan bahwa pemaafan merupakan motivasi individu melepaskan kebencian, penilaian negatif, dan perilaku acuh tak acuh terhadap pihak yang menyakiti, sehingga timbul dorongan akan kasih sayang terhadap orang yang menyakiti. Terdapat dua bentuk pemaafan, yaitu pemaafan perilaku (decisional forgiveness; menyangkut perubahan perilaku terhadap pihak yang dianggap menyakiti) dan pemaafan emosional (emotional forgiveness; ditandai dengan perubahan emosi negatif yang tak termaafkan ke emosi positif) (Worthington Jr., 2005).

Worthington Jr. dan Wade (1999) mengemukakan dua konsep mengenai keputusan individu dalam memaafkan, yaitu: 1). unforgiveness, meliputi kebencian, kepahitan, penghindaran, dan motivasi untuk membalas dendam terhadap pihak yang dianggap bersalah (transgressor) dan 2). forgiveness, merupakan pilihan individu yang disadari untuk berusaha memperbaiki hubungan dengan orang yang dianggapnya bersalah. Keduanya saling terkait satu sama lain dan dapat digambarkan dalam sebuah siklus yang disebut proses interpersonal dalam pemaafan (interpersonal process of forgiveness and unforgiveness).

Penelitian Ronel dan Lebel (2006) menemukan bahwa sebagian besar orang tua masih memiliki amarah terhadap teroris yang menyebabkan anak mereka meninggal, sehingga pengampunan menjadi hampir mustahil. Hanya ada beberapa orang tua yang menyatakan kemungkinan terjadinya pengampunan dan rekonsiliasi terhadap teroris. Studi Martinčeková dan Klatt (2016) terhadap ibu yang kehilangan anaknya menemukan bahwa mayoritas partisipan merasakan penyesalan, rasa bersalah, dan amarah pada orang lain, juga Tuhan pada awalnya, kemudian terdapat proses pemaafan terhadap diri sendiri, orang lain, dan Tuhan. Partisipan yang telah mencapai proses pemaafan selanjutnya dapat mengalami perubahan positif pasca peristiwa traumatis (post traumatic growth), yang meliputi adanya perubahan nilai kehidupan, perubahan relasi dengan orang lain, kekuatan personal yang lebih tinggi, perubahan spiritualitas dan aktualisasi diri. 


\section{Tujuan Studi}

Studi ini bertujuan untuk mengeksplorasi bagaimana proses pemaafan pada individu yang kehilangan anggota keluarga akibat peristiwa bom di Surabaya. Walau studi internasional mengenai pemaafan cukup banyak dilakukan (cth. Ronel \& Lebel, 2007; Martinčeková \& Klatt, 2016), namun penelitian dalam konteks kehilangan anggota keluarga lain selain anak belum banyak diteliti. Studi ini secara spesifik menggunakan teori interpersonal process of forgiveness and unforgiveness yang dikemukakan oleh Worthington Jr. dan Wade (1999) sebagai kerangka berpikir dalam memahami proses dinamika pemaafaan pada keluarga korban ledakan bom Surabaya 2018.

\section{METODE}

\section{Partisipan}

Partisipan penelitian direkrut melalui teknik purposive sampling dengan karakteristik partisipan ialah: 1). anggota keluarga korban inti ledakan bom di Surabaya yang kehilangan anggota keluarganya; dan 2). bersedia dan sanggup untuk diwawancarai dalam proses pengambilan data. Pencarian partisipan dilakukan dengan meminta bantuan dari beberapa orang jemaat gereja yang kebetulan mengenal partisipan. Peneliti menjelaskan mengenai kerahasiaan data, perizinan perekaman, penggunaan data untuk kepentingan penelitian, dan haknya untuk mengundurkan diri. Peneliti juga mempersiapkan bantuan psikolog jika dampak negatif muncul pada partisipan. Partisipan diminta menandatangani informed consent sebelum diwawancara.

Penelitian ini melibatkan dua orang partisipan. Partisipan pertama (P1) adalah seorang pria berusia 47 tahun yang bekerja sebagai wiraswasta. P1 memiliki tiga orang anak. Anak pertamanya sudah bekerja dan menikah. Anak keduanya meninggal akibat peristiwa bom Surabaya 2018. Anak terakhirnya berusia 8 tahun. Saat kejadian, P1 berada di lingkungan gereja, tetapi cukup jauh dari lokasi ledakan. Saat keberadaan anaknya belum ditemukan, P1 sangat khawatir dan mencarinya di berbagai rumah sakit di Surabaya. Jenazah anak P1 teridentifikasi 2 hari pasca kejadian melalui tes DNA.

Partisipan kedua (P2) adalah seorang wanita berusia 37 tahun yang bekerja sebagai pengajar. Saat kejadian, P2 kehilangan suaminya yang saat itu sedang berada di gereja. Pada saat itu, P2 sedang berada di rumah sehingga belum mengetahui adanya insiden ledakan bom di gereja. Saat mengetahui terjadi ledakan di gereja, P2 mencemaskan keberadaan suaminya, terutama ia berupaya menghubungi suaminya berkali-kali melalui telepon dan tidak mendapat respons. P2 baru 
mengetahui bahwa suaminya menjadi korban setelah mendapat kabar dari saudaranya. Setelah menunggu 1 minggu, jenazah suami P2 baru dapat ditemukan karena menunggu proses forensik.

\section{Desain}

Metode penelitian yang digunakan adalah penelitian kualitatif deduktif dengan menggunakan Teori Interpersonal Process of Forgiveness and Unforgiveness (Worthington Jr. \& Wade, 1999) sebagai kerangka berpikir. Penelitian ini menggunakan teori dan studi pustaka sebagai kerangka berpikir yang kemudian dirumuskan menjadi hipotesis kerja. Hipotesis kerja berfungsi sebagai dugaan awal yang disusun peneliti untuk mencari jawaban yang holistik dan terintegrasi melalui penelitian yang akan dilakukan. Selain itu, teori dan studi pustaka berfungsi untuk mengetahui kesenjangan dalam penelitian (Poerwandari, 2007).

\section{Prosedur}

Teknik pengumpulan data diperoleh dengan wawancara mendalam sesuai dengan panduan wawancara yang dikembangkan peneliti. Partisipan mengikuti dua sesi wawancara dengan waktu sekitar 2-3 jam untuk setiap sesinya. Seluruh sesi wawancara direkam dengan alat perekam suara dan disusun menjadi sebuah transkrip wawancara untuk dianalisis. Metode keabsahan dilakukan menggunakan member check, yaitu meminta partisipan untuk melakukan verifikasi ketepatan data atau mengklarifikasi data yang kurang tepat melalui salinan transkrip wawancara yang diberikan (Creswell, 2015).

\section{Teknik Analisis}

Teknik analisis yang digunakan ialah analisis tematik. Tahapan yang dilakukan adalah membaca dan memahami transkrip, menyusun kode seluruh transkrip, mengklasifikasikan beberapa kode menjadi tema, mengevaluasi relevansi tema yang ada dengan data (membaca kembali transkrip), memberi nama dan mendefinisikan tema, dan memilih kutipan yang tepat untuk mempresentasikan tema-tema (Braun \& Clarke, 2006).

\section{Posisi Relatif Peneliti}

Pengaruh narasi "tidak membalas kejahatan dengan kejahatan" tentunya sangat memengaruhi cara pandang peneliti terhadap topik dalam penelitian ini. Hal ini merupakan sisi baik manusia, di mana manusia sebagai makhluk yang dikaruniai akal budi dapat mempertimbangkan 
standar moral yang bijak dan adaptif. Di sisi lain, peneliti juga memahami bahwa manusia memiliki sisi baik dan sisi jahat, sehingga narasi "nyawa ganti nyawa", yang berarti sesuatu yang jahat harus dibalas dengan yang seberat-beratnya juga mungkin terjadi, meski menurut peneliti cara berpikir demikian merupakan bentuk reaksi yang tidak adaptif bagi manusia. Hal tersebut memengaruhi bagaimana peneliti berempati atas pengalaman partisipan (di mana setiap partisipan memiliki sisi baik dan jahat) dan memahami konteks individu yang kehilangan anggota keluarga.

Selain itu, peneliti juga memiliki pengalaman secara langsung terlibat dalam sebuah yayasan pemulihan kesehatan mental yang secara tidak langsung memengaruhi cara pandang peneliti mengenai respons emosi yang maladaptif. Peneliti pernah mewawancarai seseorang yang mengalami gangguan delusi akibat kematian ayah kandungnya. Berdasarkan pengalaman tersebut, peneliti menyadari bahwa respons emosional saat kehilangan, seperti kesedihan dan kemarahan, merupakan hal yang wajar, tetapi menjadi tidak wajar jika terjadi dalam jangka panjang dan terusmenerus. Pengalaman tersebut juga memengaruhi cara pandang peneliti bahwa terdapat keterkaitan antara aspek kognitif, emosional, maupun perilaku pada individu ketika mengalami tekanan.

\section{ANALISIS DAN HASIL}

Setelah dilakukan pengumpulan dan uji keabsahan data, peneliti menganalisis data yang diperoleh. Berdasarkan hasil analisis, diperoleh empat tema utama, yaitu konteks personal (ciri kepribadian dan komitmen agama), persepsi pasca kejadian, respons emosional, dan respons perilaku.

\section{Konteks Personal: Ciri Kepribadian dan Komitmen Agama}

Ciri kepribadian dan komitmen agama merupakan faktor personal yang memengaruhi individu dalam mengambil keputusan untuk memaafkan atau tidak (Worthington Jr. \& Wade, 1999).

Ciri kepribadian agreeableness. Agreeableness merupakan ciri kepribadian yang terkait dengan sifat-sifat altruis, seperti menghindari konflik, perilaku prososial, dan memaafkan. Ciri kepribadian yang berlawanan dengan agreeableness adalah antagonisme (McCullough, 2001; John \& Srivastava, 1999). Pada P1, perilaku yang terkait dengan antagonisme tampak dalam relasi dengan anak pertamanya, ketika ia merasa dibohongi oleh anak pertamanya mengenai sumbangan uang duka yang seharusnya diterima. Uang kedukaan ini diberikan oleh beberapa orang sebagai 
bentuk simpati atas kematian anaknya yang menjadi korban ledakan bom.

\begin{abstract}
"Saya yakin Tuhan kita hiduplah, rencana Tuhan itu baik bagi keluarga kita, mungkin ada rencana bagaimana, tapi dimanfaatkan sama bekas mertuanya anakku yang pertama itu jadi dana-dana itu dikuasai sana semuanya, padahal menurut hukum dana kan dibagi sama orang tuanya sendiri tapi berhubung ada permainan kotor ya ndak papa lah, serahkan sama Tuhan saja lah, ya kita bilang sama dia orang menabur kan pasti menuai." (P1)
\end{abstract}

Ciri kepribadian stabilitas emosional. Stabilitas emosional merupakan karakteristik yang terkait dengan ketenangan emosional dan ketahanan psikis dalam menghadapi tekanan. Stabilitas emosional ini berlawanan dengan neurotisisme (McCullough, 2001; Worthington Jr. \& Wade, 1999). Pada P1, perilaku yang terkait dengan neurotisisme tampak saat P1 mengeluh karena terkadang beberapa orang tidak menghargai pekerjaannya. Sementara itu, pada P2 perilaku yang terkait dengan ciri kepribadian stabilitas emosional tampak ketika ia merasa kuat dalam menghadapi kesedihan karena kematian suaminya.

"Beban saya berat, karena ada beberapa orang yang gak bayar, tapi ya repot sama kesadarannya orang." (P1)

"Saya pribadi tidak ingin larut dalam situasi karena saya ada anak dua ini, kalo saya jatuh siapa yang mau sangga mereka berdua, karena mereka kan butuh sekali kekuatan dari saya, lalu banyak juga kekuatan yang saya dapatkan dari orang yang datang, dari orang yang melayat. Jadi ya kekuatan banyak sih, intinya kalo saya mengikhlaskan Tuhan pakai dia untuk jadi saluran kemuliaan-Nya kenapa saya harus sedih." (P2)

Komitmen agama. Komitmen agama merupakan tingkat kesetiaan individu dalam mengikuti nilai, ritual, dan keyakinan agamanya, serta menerapkannya dalam kehidupan sehari-hari (Worthington Jr. \& Wade, 1999). Pada P2, komitmen agama terlihat saat P2 menjadikan ajaran agamanya sebagai referensi dalam memaafkan pelaku (teroris) yang menyebabkan kematian suaminya.

"Saya memahami ampuni saudaramu tujuh puluh kali tujuh kali itu benar-benar saya maknai itu, bahwa saya harus memaafkan pelaku." (P2) 


\section{Persepsi Pasca Kejadian}

Persepsi sangat menentukan bagaimana sikap, emosi, dan perilaku individu, termasuk memengaruhi keputusan individu dalam memaafkan transgressor atau pihak yang dianggap bersalah (Worthington Jr. \& Wade, 1999; Zamuner, 2015). Persepsi positif mendukung proses pemaafan, sedangkan persepsi negatif menghambat proses pemaafan. Dalam tema ini, persepsi meliputi persepsi terhadap pelaku (teroris), diri, situasi, dan Tuhan.

Persepsi terhadap pelaku (teroris). P1 memandang teroris sebagai pihak yang bersalah. Menurutnya perbuatan teroris yang tidak manusiawi tersebut disebabkan karena teroris sudah dipengaruhi oleh sekelompok orang dengan paham radikalisme. Kejadian tersebut merugikan banyak pihak, termasuk mengakibatkan anaknya meninggal. Sementara itu, P2 memandang teroris sebagai pihak yang tidak patut untuk disalahkan karena P2 memahami motivasi teroris melakukan bom bunuh diri adalah karena pengaruh doktrin yang salah, sehingga mereka tidak sepenuhnya bersalah.

"Yang paling bersalah itu yang nyuci otak itu, yang menyuruh itu yang paling bersalah.” (P1)

"Saya menyadari mungkin mereka juga salah satu korbannya dari doktrin yang sudah ditanamkan dari kecil yang salah yang benar-benar mengakar dalam diri mereka." (P2)

Persepsi terhadap diri. P1 memandang dirinya sebagai orang tua yang terbaik bagi anaknya sewaktu masih hidup, sehingga ketika anaknya meninggal P1 tidak menyalahkan diri atas apa yang terjadi padanya. Sementara itu, P2 memandang dirinya sebagai istri yang belum sempurna karena ia merasa masih kerap melakukan kesalahan pada suaminya sewaktu hidup berumah tangga.

"Saya sudah mengarahkan anak, tanggung jawab sama anak, sudah membimbing dia dengan kasih dan agama yang benar, kebutuhan sudah tercukupi setiap hari." (P1)

"Iya (perasaan bersalah) dari hubungan saya, dari awal bertemu lalu tiba-tiba tidak bertemu sama sekali itu kan ada rasa penyesalan saya dengan dia, mungkin selama ini hubungan saya sering marah atau mungkin perkataan saya mungkin dia sedih itu juga." (P2) 
Persepsi terhadap situasi. P1 memandang bahwa, meskipun insiden tersebut merupakan momen yang tidak terpikirkan sebelumnya serta tidak seharusnya terjadi, ia dapat menerimanya sebagai sesuatu yang di luar kontrol dirinya. Sementara itu, P2 terkesan kurang dapat menerima situasi yang terjadi dengan mempersepsikan bahwa apa yang terjadi di gereja seharusnya tidak menyebabkan suaminya menjadi korban, jika suaminya tidak berada di dekat teroris.

“Ya kehendak Tuhan kita ndak mengerti ya to akhirnya yaa terjadi itu bom." (P1)

"Cuman ya saat itu masih berharap sebenarnya bukan dia, mungkin orang lain kah yang disitu atau bagaimana masih ada harapan seperti itu.” (P2)

Persepsi pada Tuhan. P1 memandang Tuhan sebagai figur yang kejam dan tidak adil atas kematian anaknya pada saat mengetahui bahwa anaknya menjadi korban ledakan bom. Sementara itu, P2 memang memandang Tuhan sebagai figur yang baik karena telah merasakan kebaikan Tuhan, walaupun peristiwa tersebut sangat menyedihkan baginya.

“Pada awalnya saya memandang Tuhan kok gak adil.” (P1)

"Saya dari awal kejadian itu sampai sekarang memang saya tetap memandang Tuhan itu baik.” (P2)

\section{Respons Emosional}

Respons emosional individu sangat ditentukan oleh bagaimana persepsi individu terhadap kejadian. Respons emosional mencakup kemarahan karena adanya persepsi negatif (lihat tema sebelumnya), kesedihan, dan ruminasi.

Kesedihan. Pada saat kehilangan anaknya, P1 merasakan kesedihan dan kekecewaan karena kehilangan anak yang disayanginya. Begitu pula dengan P2, yang juga merasakan kesedihan pasca kejadian tersebut karena kehilangan suaminya, juga karena kedua anaknya ditinggal oleh ayahnya.

"Sebenarnya sedih lah, kalau orang tua kehilangan anak kan pastinya sedih mas, anak yang besok-besok sebagai gantiku ternyata diambil Tuhan, ya ndak papa." (P1)

"Yang saya rasakan waktu itu lebih ke sedih, sedih karena dia gak ada sedih karena dua anak ini tidak bisa lihat papanya lagi rasa sedih seperti itu yang saya rasakan." (P2) 
Ruminasi. Pasca kejadian, P1 sering teringat akan kematian anaknya, terlebih ketika sedang berada di gereja. Setiap teringat akan anaknya, P1 merasa sedih dan membuat dirinya sangat sulit untuk menerima kenyataan. P2 juga mengalami hal yang sama, di mana ia terkadang teringat akan suaminya dan menangis ketika mengingat insiden tersebut. Selain itu, P2 menyesalkan posisi suaminya yang saat itu berada di gereja dan sering berandai-andai bahwa bukan suaminya yang menjadi korban. P2 juga teringat akan kesalahan yang pernah dilakukan selama bersama suaminya.

"Ya masih terbayang dia. Maksudnya di hati sebagai orang tua kan mesti terbayang apalagi kejadiannya di gereja, jadi setiap kali ke gereja selalu ingat." (P1)

"Kalo teringat ya menangis, terus rasa rindu itu memang masih sangat fluktuatif dulu sangat terasa." (P2)

\section{Respons Perilaku}

Perilaku individu sangat ditentukan oleh bagaimana persepsinya terhadap kejadian. Dalam tema ini, perilaku dapat ditujukan sebagai respons terhadap pelaku teroris (balas dendam dan empati terhadap situasi dengan menyangkal kejadian dan menerima kenyataan), terhadap Tuhan (menjauhi dan bersyukur pada Tuhan), dan terhadap diri (menyalahkan diri, penghargaan diri, dan motivasi diri).

Balas dendam dan berempati. Beberapa warga Surabaya menolak jenasah para teroris untuk dimakamkan karena mereka telah meresahkan masyarakat (Islam, 2018). Mengenai hal ini, P1 dan P2 memiliki perbedaan pandangan dalam menyikapi hal tersebut. P1 menganggap bahwa sudah selayaknya teroris (baik yang dicuci otak maupun yang mencuci otak) mendapatkan balasan yang setimpal. P1 juga menganggap bahwa sudah sepatutnya teroris tidak mendapatkan makam; ia tidak rela jika teroris dimakamkan di sekitar tempat tinggalnya. Sementara itu, P2 justru tidak memiliki keinginan agar teroris mendapat hukuman karena merasa bukan haknya untuk mengadili. P2 bahkan merasa kasihan karena teroris tidak mendapatkan makam. P2 pun secara sadar mendoakan teroris.

"Kita ndak boleh dendam biar Tuhan yang menghukum dia, orang menabur kan pasti menuai... Ya gak rela [jika teroris dimakamkan di dekat tempat tinggal P1], waktu pemakaman teroris itu kan juga diusir sama orang setempat.” (P1)

"Enggak sih (keinginan pelaku supaya dihukum tuhan), itu sudah di luar kapasitas saya sebagai manusia ya karena Tuhan punya kuasanya sendiri, punya 
pertimbangannya sendiri, berat ringan itu kan Tuhan yang punya kekuasaan penuh... Dan saat itu malam saya secara sadar mendoakan pelaku, kasihan juga dia dimakamkan dimana-mana ditolak, itu kan saya sendiri juga kasihan kalo memang meninggal ya seharusnya dimakamkan dengan selayaknya. ”(P2)

Menyangkal kejadian dan menerima kenyataan. P1 belum dapat menerima kenyataan bahwa anaknya menjadi korban karena ia menganggap bahwa belum waktunya sang anak meninggal. Sementara itu, P2 pada awalnya menyayangkan keberadaan suaminya yang saat itu di gereja, sehingga terkena ledakan bom dan menolak untuk menerima kenyataan bahwa suaminya meninggal. P2 juga mengalami disonansi antara menerima atau menolak kenyataan bahwa suaminya menjadi salah satu korban. Namun demikian, pada akhirnya P2 menerima kenyataan tersebut sebagai sebuah memori yang perlu untuk dikenang menganggap bahwa kehilangan suaminya merupakan persembahan untuk Tuhan.

"Saya yakin dan percaya dia masuk surga, dia kan belum waktunya meninggal, rencana Tuhan gitu ya serahkan sama Tuhan saja.” (P1)

"Saya melihat videonya cctv itu juga yang saya pikirkan kenapa kamu kok di situ, kalo kamu gak di situ kan kamu gak kena, kesedihan itu yang saya rasakan... Intinya kalo saya mengikhlaskan Tuhan pakai dia untuk jadi saluran kemuliaan namanya kenapa saya harus sedih.” (P2)

Menjauhi Tuhan dan bersyukur pada Tuhan. Pasca kejadian, P1 merasa marah dan tidak terima pada Tuhan karena merasa bahwa anaknya sudah melakukan pelayanan, tetapi meninggal di usia yang masih muda. Hal ini membuat P1 merasa kepercayaannya pada Tuhan tidak membuahkan hasil yang sesuai dengan harapannya. Sementara itu, P2 merasa sangat bersyukur dan memiliki kepercayaan bahwa kuasa Tuhan akan menolong melalui dukungan orang-orang terdekat. Menurut P2, kejadian tersebut memang membuatnya sangat bersedih, tetapi P2 menerima dan mensyukuri kejadian tersebut sebagai kehendak Tuhan.

"Ya pastinya menggerutu kok Tuhan gak adil, padahal anakku ya tak suruh pelayanan tak suruh melayani drum di kaum muda kenapa begitu cepat diambil." (P1)

"Dalam kejadian ini pun saya tidak ada sedikitpun hilang dari rasa bersyukur itu gak ada, karena tangan Tuhan itu banyak, maksudnya saya gak duga, saya gak memperkirakan sebelumnya bahwa Tuhan sudah mempersiapkan begitu banyak 
tangan untuk menopang saya." (P2)

Menyalahkan diri, penghargaan diri dan motivasi diri. Pasca kejadian tersebut, P1 merasa bangga dengan dirinya karena telah memberikan yang terbaik bagi anaknya selama hidup hingga saat mencari jenazah anaknya pasca kejadian. Sementara itu, P2 memiliki perasaan bersalah dalam dirinya karena pernah melakukan beberapa kesalahan pada suaminya selama berumah tangga dan sampai saat ini P2 memohon ampun dari Tuhan atas kesalahan yang pernah dilakukan pada sang suami dan berusaha untuk memaafkan dirinya sendiri.

"Pikiran kita pasca kejadian kita sebagai orang tua sudah bertanggung jawab lah, mencari dia puji Tuhan sudah ketemu, lalu dimakamkan dengan layak.” (P1)

"Ini perasaan bersalah saya, saya belum bisa kasih yang terbaik selama ini ada hal yang bikin, kan rumah tangga gak seterusnya lurus, mungkin ada tengkar, mungkin ada hal yang bikin dia merasa gak enak itu yang akhirnya saya harus memaafkan situasi itu dan memaafkan diri saya sendiri, ya itu yang sampai sekarang saya mohon pengampunan dari Tuhan, karena saya belum sempat bilang, ya gak tahu mungkin ada sesuatu yang gak enak di saya yang di dia belum selesai itu yang bikin ada ganjalan ya itu sih." (P2)

Pasca kejadian, P1 memiliki motivasi untuk tidak larut dalam kesedihan karena masih memiliki tanggung jawab pada anaknya yang terakhir. Bagi P1, mengalihkan perhatian kepada anaknya yang terakhir dapat mengurangi emosi negatif yang dirasakannya. Begitu pula dengan P2, yang pada awalnya merasakan kesedihan akibat peristiwa tersebut, tetapi pada akhirnya mampu untuk bangkit dari kesedihan dan memiliki motivasi untuk fokus mendidik kedua anaknya.

"Jadi sekarang ya aku fokus ke anakku yang kecil, maksudnya kan masih ada anak lah, kita gak boleh lihat ke belakang tapi harus lihat kedepan lah, kasian nanti anak dan istriku kalo sedih terus kan rugi sendiri mas." (P1)

"Sekarang saya berusaha membimbing mereka dengan baik dan lebih bijaksana, ya saya menyadari saya single parent memang jadi peran kedua orang tua ada di saya." (P2) 


\section{DISKUSI}

Hasil studi ini menunjukkan bahwa pemaafan tidak hanya terbatas pada individu lain yang dianggap memiliki kesalahan, tetapi juga pada diri sendiri, pada situasi (Lopez, Pedrotti, \& Snyder, 2019), dan pada Tuhan (Exeline, Yali, \& Lobel, 1999). Pemaafan merupakan proses yang dinamis, di mana individu dapat mengalami perubahan dari forgiveness ke unforgiveness dan juga sebaliknya, sehingga hasil studi ini menunjang teori mengenai proses interpersonal dari pemaafan. Dinamika dalam proses pemaafan dapat dipengaruhi karena adanya perubahan persepsi pada individu terhadap pihak yang dianggap bersalah (transgressor). Pemaafan diawali dari konteks personal hingga setelah terjadinya pemaafan, maka individu mengalami perubahan positif dalam dirinya baik pada perilaku, pikiran, dan perasaan yang sebelumnya dipenuhi emosi dan pikiran negatif (Worthington Jr. \& Wade, 1999).

Studi ini menunjukkan bahwa faktor persepsi dan karakteristik personal memainkan peranan besar bagi individu untuk memaafkan. Faktor personal seperti stabilitas emosioanl, ciri kepribadian agreeableness, dan komitmen agama sangat memengaruhi partisipan dalam mengambil keputusan besar untuk memaafkan (Worthington Jr. \& Wade, 1999; Ajmal, Amin, \& Bajwa, 2016). Temuan dalam penelitian ini menunjukkan bahwa pada P1 ditemukan perilaku yang terkait dengan ciri kepribadian antagonisme dan neurotisisme yang menghambat proses pemaafan. Sementara itu, pada P2 ditemukan perilaku yang terkait dengan stabilitas emosional dan komitmen agama yang terkait dengan pemaafan. Persepsi juga memegang peranan penting dalam memengaruhi proses pemaafan. Menurut Zamuner (2015), emosi merupakan sebuah reaksi terhadap persepsi individu atas kejadian. Pemaafan sangat terkait pada persepsi mengenai pihak yang dianggap bersalah. Setiap individu memiliki persepsi yang berbeda dalam merespons peristiwa menyakitkan yang dilakukan oleh individu yang dianggap bersalah. Dalam penelitian ini, ditemukan bahwa persepsi positif menimbulkan emosi yang positif dan begitupula sebaliknya.

Dalam konteks kehilangan anggota keluarga akibat bencana teknologi, persepsi sangat memengaruhi respons individu (baik respons perilaku maupun respons emosi) terhadap pihak yang dianggap bersalah (Worthington Jr. \& Wade, 1999). Pada P2, tidak terdapat adanya unforgiveness pada pelaku (teroris) dan pada Tuhan, tetapi dalam konteks pada diri dan situasi terlihat adanya unforgiveness yang kemudian mengalami perubahan menjadi forgiveness. Sementara itu, pada P1, tidak terdapat adanya unforgiveness pada diri pasca kematian anaknya, tetapi dalam konteks pada pelaku (teroris), pada Tuhan, dan pada kejadian terdapat adanya unforgiveness yang belum 
mengalami perubahan menjadi forgiveness. Ketika individu diperhadapkan pada peristiwa menyakitkan yang dilakukan oleh pelaku, responsnya tidak selalu berada dalam disonansi antara memaafkan atau tidak. Individu dapat merespons dengan perilaku positif (seperti perilaku altruis pada pihak yang bersalah, bersyukur pada Tuhan, motivasi diri, dan penghargaan diri) yang tidak diawali dengan unforgiveness pada pihak yang terkait (teroris, Tuhan, situasi, dan diri sendiri).

Temuan dalam penelitian ini menunjukkan bahwa terdapat adanya perilaku altruis yang tidak diawali oleh unforgiveness. Hal tersebut terdapat pada P2 yang menyayangkan sikap warga yang menolak pemakaman pelaku (teroris) dan beranggapan bahwa sudah selayaknya mereka dimakamkan secara manusiawi, bahkan P2 mendoakan pelaku agar mendapatkan ampunan dari Tuhan. Sebaliknya P1 justru menganggap bahwa sudah sepantasnya bagi para pelaku tidak mendapatkan makam karena mereka telah merugikan banyak orang atas perbuatannya. Peneliti menyimpulkan terdapat besarnya peran ciri kepribadian agreeableness dan kuatnya komitmen agama pada individu dalam munculnya empati terhadap pelaku yang dianggap bersalah (Worthington Jr. \& Wade, 1999).

Bencana yang disebabkan oleh ulah manusia dapat membuat individu menyalahkan berbagai pihak atas kematian anggota keluarganya, sehingga dapat memengaruhi pemaafan. Namun, hal ini semua tergantung pada bagaimana persepsi individu atas bencana tersebut. Setiap individu dapat memiliki persepsi yang berbeda walaupun mengalami bencana yang sama dan individu dapat mengalami gejala maladaptif, sementara individu lainnya menunjukkan ketahanan dan pertumbuhan pasca trauma (Schulenberg, 2016). Temuan pada penelitian ini menunjukkan bahwa ketika individu memiliki persepsi yang negatif terhadap pelaku (teroris), maka akan timbul kemarahan dalam diri individu terhadap pelaku tersebut, sehingga sangat sulit bagi individu untuk mencapai pemaafan. Sebaliknya, ketika individu mampu untuk memahami sudut pandang pelaku sebagai korban doktrin, maka akan timbul empati, tidak adanya penyalahan pada pelaku, dan perilaku altruis seperti mendoakan pelaku agar mendapatkan ketenangan. Temuan ini sejalan dengan penelitian Ronel dan Lebel (2006) dan Saka dan Cohen-Louck (2014) mengenai kemarahan dan pemaafan orang tua atas kematian anak akibat bencana teknologi. Namun, sejauh ini belum ada penelitian mengenai respons kemarahan dan pemaafan pada konteks kehilangan pasangan hidup akibat ulah orang lain, sehingga penelitian berikutnya sangat dibutuhkan.

Kesedihan akibat kematian anggota keluarga merupakan hal yang wajar, terlebih jika kematian tersebut mendadak dan tanpa diprediksi sebelumnya. Kematian anggota keluarga secara mendadak karena peristiwa kekerasan dapat menimbulkan complicated grief, yaitu keinginan kuat 
untuk bertemu dengan individu yang sudah meninggal, kesulitan menerima peristiwa kematian, dan kesulitan untuk melanjutkan hidup (Prigerson dkk., 2009). Dalam penelitian ini, ditemukan bahwa kedua partisipan mengalami kesulitan menerima peristiwa kematian dan memiliki keinginan yang kuat untuk bertemu anggota keluarga yang meninggal, tetapi salah satu partisipan akhirnya mampu untuk menerima kematian suaminya dan melanjutkan kehidupan tanpa adanya emosi negatif akibat kematian suaminya. Sementara itu, pada partisipan lainnya ditemukan masih terdapat emosi negatif akibat kematian anaknya hingga saat ini. Complicated grief dapat menghambat pemaafan individu terhadap situasi karena individu masih belum mampu menerima kehilangan orang terdekatnya. Peneliti berasumsi bahwa penerimaan individu atas kematian orang terdekatnya dapat mengurangi kesedihan dan emosi negatif lainnya. Asumsi tersebut sejalan dengan penelitian Ronel dan Lebel (2006) dan Martinčeková dan Klatt (2016).

Dalam penelitian ini juga ditemukan bahwa ruminasi sangat memengaruhi kesedihan dan emosi negatif lainnya yang semakin parah pada individu. Ruminasi yang dialami oleh partisipan adalah ingatan terus menerus mengenai situasi saat kematian anggota keluarga dan kesalahan yang pernah dilakukan partisipan terhadap suami selama masih hidup. Ruminasi dapat menghambat pemaafan pada individu karena individu memikirkan secara terus menerus pihak yang dianggap bersalah (McCullough, 2000, 2001; Nolen-Hoeksema \& Davis, 1999).

Dalam menghadapi sebuah krisis kehidupan, individu yang memiliki kepercayaan akan kekuatan Ilahi akan dihadapkan pada disonansi persepsi antara memandang figur Tuhan secara positif atau negatif. Bahkan, individu sering mempersepsikan bahwa Tuhan telah menyebabkan penderitaan dan ketidakadilan yang terjadi pada dirinya (Exline, 2010). Persepsi negatif atas figur Tuhan akan menimbulkan perasaan marah pada Tuhan atas kejadian yang dialaminya (Exline, Park, Smyth, \& Carey, 2011). Temuan penelitian ini menunjukkan bahwa kemarahan pada Tuhan disebabkan oleh persepsi individu bahwa Tuhan telah menyebabkan penderitaan dan kesedihan yang dialaminya. Temuan dalam penelitian ini juga menunjukkan bahwa individu tidak selalu mempersepsikan Tuhan sebagai figur yang kejam dan tidak adil atas krisis kehidupan yang dialaminya. Bahkan, individu dapat bersyukur walaupun mengalami krisis kehidupan yang sangat menyedihkan dan kehilangan orang terdekatnya. Ketika individu memiliki persepsi positif pada figur Tuhan maka individu akan percaya bahwa setiap kebaikan yang didapat berasal dari Tuhan yang dipercaya. Persepsi yang positif atas figur Tuhan merupakan proses coping agama yang positif. Menurut Gerber, Boals, dan Schuettler (2011), coping agama yang positif (seperti dukungan spiritual, penilaian agama yang penuh kebajikan, dan pengampunan) berkontribusi terhadap 
pertumbuhan pasca trauma.

Temuan penelitian ini juga menunjukkan adanya perasaan bersalah pada individu pasca kematian anggota keluarga. Hal ini terlihat pada P2 ketika ia merasa dirinya belum mampu menjadi istri yang terbaik semasa hidup sang suami, sementara pada partisipan lain (P1) tidak ditemukan adanya perasaan bersalah. Hal tersebut dikarenakan P1 merasa sudah memberikan yang terbaik pada anaknya selama masih hidup. Rasa bersalah ini dapat disebabkan karena individu belum melepaskan kebencian atas dirinya sendiri dan menggantinya dengan belas kasih dan cinta terhadap diri sendiri (Enright, 1996). Sebaliknya, tidak adanya perasaan bersalah dapat disebabkan oleh persepsi individu karena merasa memiliki relasi yang baik dengan anggota keluarga yang meninggal. Namun, tidak menutup kemungkinan bahwa individu juga menghindari pikiran dan perasaan bersalah yang dialaminya (Hall \& Fincham, 2005). Temuan dalam penelitian ini juga menunjukkan bahwa ketika individu mampu memiliki sikap positif pada dirinya sendiri, maka akan timbul respons kasih sayang pada diri sendiri berupa penghargaan diri atau motivasi diri. Motivasi diri menjadikan individu semakin terpacu untuk melakukan aktivitas sehari-hari dan mencapai tujuan hidup secara adaptif dengan meninggalkan emosi kesedihan yang dialami.

\section{SIMPULAN DAN SARAN}

\section{Simpulan}

Studi ini menunjukkan bahwa proses pemaafan dapat berbeda antara satu individu dan individu yang lain. Perbedaan tersebut dapat disebabkan oleh ciri kepribadian, komitmen agama, dan persepsi terhadap kejadian yang memengaruhi respons emosional dan perilaku individu. Ketika individu memutuskan untuk memaafkan, maka individu mengalami adanya perubahan yang semula mengalami unforgiveness menjadi forgiveness. Perubahan tersebut mencangkup kognitif (persepsi), emosional, dan perilaku terhadap pihak yang dianggap bersalah. Sebaliknya, ketika individu belum memaafkan (masih berada pada kondisi unforgiveness), maka individu masih diliputi oleh emosi negatif, seperti masih adanya motivasi untuk membalas dendam dan kemarahan. Proses pemaafan pada individu merupakan proses yang dinamis, di mana individu dapat mengalami perubahan dari unforgiveness menuju forgiveness, dan begitu pula sebaliknya. 


\section{Saran Teoretis}

Penelitian selanjutnya diharapkan lebih berfokus pada satu keluarga inti untuk mendapatkan perbedaan respons dan dampak emosi yang terdapat pada setiap anggota keluarga yang kehilangan orang terdekatnya, serta bagaimana keterkaitan antara anggota keluarga yang satu dengan yang lainnya dalam merespons kehilangan. Hal tersebut diperlukan mengingat sejauh ini penelitian dalam konteks bencana teknologi hanya berfokus pada salah satu anggota keluarga saja, bukan pada satu keluarga inti secara utuh.

\section{Saran Praktis}

Nilai-nilai keagamaan dapat memfasilitasi individu untuk memaafkan pihak yang dianggap bersalah. Oleh sebab itu, penting untuk berfokus pada penguatan nilai-nilai pemaafan, empati, kebersyukuran dan toleransi yang terdapat pada ajaran agama, bukan hanya sebatas doktrin tetapi juga pada sisi aplikasinya. Agama juga memberikan sarana bagi individu dalam pemaknaan yang positif melalui campur tangan Tuhan yang dipercaya oleh setiap individu di tengah krisis kehidupan yang dialami. Selain itu, dukungan sesama umat pada individu yang mengalami musibah dapat memampukan individu untuk mengatasi gejolak emosi negatifnya. Dengan adanya dukungan yang diterima, individu diharapkan semakin mampu bersyukur dan mengapresiasi diri dan situasi yang diizinkan terjadi, sehingga tidak larut dalam kesedihan dan mampu untuk menerima situasi.

\section{REFERENSI}

Abidin, Z. (2018). Monique istri Bayu telah memaafkan pelaku teror bom. Suarasurabaya.net. Ditemu kembali dari https://www.suarasurabaya.net/kelanakota/2018/Monique-Istri-BayuTelah-Memaafkan-Pelaku-Teror-Bom/

Ajmal, A., Amin, R., \& Bajwa, R. S. (2016). Personality traits as predictors of forgiveness and gratitude. Pakistan Journal of Life and Social Sciences, 14(2), 91-95.

Braun, V., \& Clarke, V. (2006). Using thematic analysis in psychology. Qualitative Research in Psychology, 3(2), 77-101.

Creswell, J. W. (2015). Penelitian kualitatif \& desain riset: Memilih di antara lima pendekatan. Pustaka Pelajar.

Enright, R. D. (1991). The moral development of forgiveness. Dalam W. Kurtines \& J. Gewirtz (Eds.), Handbook of moral behavior and development (hlm. 123-152). Erlbaum. 
Enright, R. D. (1996). Counseling within the forgiveness triad: On forgiving, receiving forgiveness, and self-forgiveness. Journal of Counseling and Values, 40(2), 107-126.

Exline, J. J. (2010). Anger toward God: A new frontier in the study of forgiveness. Dalam M. R Maamri, N. Verbim \& E. L. Worthington, Jr. (Eds.), A journey through forgiveness (hlm. 29-37). Oxford University Press.

Exline, J. J., Park, C. L., Smyth, J. M., \& Carey, M. P. (2011). Anger toward God: Social-cognitive predictors, prevalence, and links with adjustment to bereavement and cancer. Journal of Personality and Social Psychology, 100(1), 129-148. doi: 10.1037/a0021716

Exline, J. J., Yali, A. M., \& Lobel, M. (1999). When God disappoints: Difficulty forgiving God and its role in negative emotion. Journal of Health Psychology, 4(3), 365-379.

Gerber, M. M., Boals, A., \& Schuettler, D. (2011). The unique contributions of positive and negative religious coping to posttraumatic growth and PTSD. Psychology of Religion and Spirituality, 3(4), 298-307. doi: 10.1037/a0023016

Hall, J. H., \& Fincham, F. D. (2005). Self-forgiveness: The stepchild of forgiveness research. Journal of Social and Clinical Psychology, 24(5), 621-637.

Islam, S. (2018). Warga tolak jenazah 1 keluarga terduga teroris dimakamkan di Surabaya. Okenews. Ditemu kembali dari https://news.okezone.com/read/2018/05/14/519/1898261/ warga-tolak-jenazah-1-keluarga-terduga-teroris-dimakamkan-di-surabaya.

John, O. P., \& Srivastava, S. (1999). The Big Five trait taxonomy: History, measurement, and theoretical perspectives. Dalam L. A. Pervin \& O. P. John (Eds.), Handbook of personality: Theory and research (hlm. 102-138). Guildford Press.

Kami, I. M. (2018). 11 korban tewas, ini yang diketahui dari ledakan bom di Surabaya. Detik News. Ditemu kembali dari https://news.detik.com/berita/d-4018147/11-korban-tewas-ini-yangdiketahui-dari-ledakan-bom-di-surabaya

Kholik, A., \& Himam, F. (2015). Konsep psikoterapi kawruh jiwa Ki Ageng Suryomentaram. Gadjah Mada Journal of Psychology, 1(2), 120-134. doi: 10.22146/gamajop.7349

Kisah haru Wenny, ibunda Evan \& Nathan maafkan pelaku bom bunuh diri. (2018). Merdeka.com. Ditemu kembali dari https://www.merdeka.com/peristiwa/kisah-haru-wenny-ibunda-evannathan-maafkan-pelaku-bom-bunuh-diri.html

Lopez, S. J., Pedrotti, J. T., \& Snyder, C. R. (2019). Positive psychology: The scientific and practical explorations of human strengths. Sage Publications. 
Martinčeková, L., \& Klatt, J. (2016). Mothers' grief, forgiveness, and posttraumatic growth after the loss of a child. OMEGA-Journal of Death and Dying, 75(3), 248-265.

McCullough, M. E. (2000). Forgiveness as human strength: Theory, measurement, and links to well-being. Journal of Social and Clinical Psychology, 19(1), 43-55.

McCullough, M. E. (2001). Forgiveness: Who does it and how do they do it? Current Directions in Psychological Science, 10(6), 194-197.

Nolen-Hoeksema, S., \& Davis, C. G. (1999). "Thanks for sharing that": Ruminators and their social support networks. Journal of Personality and Social Psychology, 77(4), 801-814. doi: 10.1037/0022-3514.77.4.801

Oliver, K. (2002). Psychology in practice: Environment. Hodden Anor.

Poerwandari, K. (2007). Pendekatan kualitatif untuk penelitian perilaku manusia. LPSP3.

Prigerson, H. G., Horowitz, M. J., Jacobs, S.C., Parkes, C. M., Aslan, M., Goodkin, K., \& Maciejewski, P. K. (2009). Prolonged grief disorder: Psychometric validation of criteria proposed for DSM-V and ICD-11. PLoS Medicine, 6(8), e1000121. doi: 10.1371/journal.pmed.1000121

Ronel, N., \& Lebel, U. (2006). When parents lay their children to rest: Between anger and forgiveness. Journal of Social and Personal Relationships, 23(4), 507-522.

Saka, Y., \& Cohen-Louck, K. (2014). From demonization to identification: How parents who lost children in terrorist attacks perceive the attacker. Journal of Loss and Trauma, 19(2), 137154.

Schulenberg, S. E. (2016). Disaster mental health and positive psychology-considering the context of natural and technological disasters: An introduction to the special issue. Journal of Clinical Psychology, 72(12), 1223-1233.

Worthington Jr., E. L. (2005). Initial questions about the art and science of forgiving. Dalam E. L. Worthington Jr. (Ed.), Handbook of forgiveness (hlm. 1-13). Brunner-Routledge.

Worthington Jr., E. L., \& Wade, N. G. (1999). The psychology of unforgiveness and forgiveness and implications for clinical practice. Journal of Social and Clinical Psychology, 18(4), 385418.

Zamuner, E. (2015). Emotions as psychological reactions. Mind and Language, 30(1), 22-43. 